\title{
Normal pressure hydrocephalus - why treatment is often delayed or not even initiated
}

Uwe Kehler

From Hydrocephalus 2015

Banff, Canada. 18-21 September 2015

Normal pressure hydrocephalus is a common disease in elderly people and treatment is beneficent. It is also well known, that delayed treatment of NPH shows worth results than early treatment. However, many patients are sent with enormous delay and or not even sent to hydrocephalus specialists. The aim of this work is to search for the reasons and discuss improvements.

\section{Methods}

The reasons for delayed treatment of NPH in patients who were treated finally in our department are summarized. Only reasons which occurred twice are mentioned not to overestimate too exceptional cases. Only cases were included who improved after shunt surgery.

\section{Results}

The reasons for delayed NPH treatment could be identified: 1: Spinal tap testing did not show clear improvement, although patient felt substantial improvement. 2: Examination of spinal tap test was done at wrong time, patient improved substantially after demission of the hospital. 3: Radiologist misdiagnosed hydrocephalus (typical wrong diagnosis: brain atrophy and/or cerebral micro-angiopathy), 4: Patient was considered to be too old for shunt surgery. 5: General physician and/or neurologist considered surgery too risky (without explaining the patient the progressive natural history of the disease). 6. NPH was not suspected by the general physician and/or neurologist or NPH was misdiagnosed as Alzheimer's disease and Parkinson's disease.

\section{Discussion}

Unawareness of NPH, general physician's and neurologist's fear of shunt complications, thoughtless radiological diagnosis of brain atrophy with excluding hydrocephalus

Correspondence: u.kehler@asklepios.com

Asklepios Hospital Hamburg Altona, Germany are some reasons why patients are sent delayed to hydrocephalus specialists. Medical education and information has to be improved that NPH patients can get the benefit of treatment as early as possible.

Published: 18 September 2015

\section{References}

1. Lemcke J, Meier U, Müller C, Fritsch M, Eymann R, Kiefer M, Kehler U, Langer N, Rohde V, Ludwig HC, Weber F, Remenez V, Schuhmann M, Stengel $D$ : Is it possible to minimize overdrainage complications with gravitational units in patients with idiopathic normal pressure hydrocephalus? Protocol of the randomized controlled SVASONA Trial (ISRCTN51046698). Acta Neurochir Suppl 2010, 106:113-5.

2. Kluge S, Baumann HJ, Regelsberger J, Kehler U, Gliemroth J, Koziej B, Klose $\mathrm{H}$, Meyer A: Pulmonary hypertension after ventriculoatrial shunt implantation. J Neurosurg 2010, 113(6):1279-83.

3. Piek J, Weber C, Kundt G, Tronnier V, Spuck S, Hirdes C, Kehler U, Ditges C: Pharmacoeconomical Consequences of Postoperative CSF Leaks after Intracranial Surgery - A Prospective Analysis. Cen Eur Neurosurg 2011 Sep 19, [Epub ahead of print].

4. Kehler U, Langer N, Gliemroth J, Meier U, Lemcke J, Sprung C, Schlosser HG, Kiefer M, Eymann R, Heese O: Reduction of shunt obstructions by using a peel-away sheath technique? A multicenter prospective randomized trial. Clin Neurol Neurosurg 2012, 114(4):381-4.

5. Lemcke J, Meier U, Müller C, Fritsch M, Kiefer M, Eymann R, Kehler U, Langer N, Schuhmann MU, Speil A, Weber F, Remenez V, Rohde V, Ludwig HC, Stengel D: On the method of a randomised comparison of programmable valves with and without gravitational units: the SVASONA study. Acta Neurochir Suppl 2012, 114:243-6.

6. Kehler U, Hirdes C, Weber C, Spuck S, Tronnier V, Kundt G, Piek J: CSF leaks after cranial surgery - a prospective multicenter analysis. Innovative Neurosurgery, Online 08/12/2012.

7. Lemcke J, Meier U, Müller C, Fritsch MJ, Kehler U, Langer N, Kiefer M, Eymann R, Schuhmann MU, Speil A, Weber F, Remenez V, Rohde V, Ludwig HC, Stengel D: Safety and efficacy of gravitational shunt valves in patients with idiopathic normal pressure hydrocephalus: a pragmatic, randomised, open label, multicentre trial (SVASONA). J Neurol Neurosurg Psychiatry 2013, 84(8):850-7.

8. Meier U, Stengel D, Müller C, Fritsch MJ, Kehler U, Langer N, Kiefer M, Eymann R, Schuhmann MU, Speil A, Weber F, Remenez V, Rohde V, Ludwig HC, Lemcke J: Predictors of subsequent overdrainage and clinical outcomes after ventriculoperitoneal Shunting for idiopathic normal pressure hydrocephalus. Neurosurgery 2013, 73(6):1054-60.

9. Fritsch M, Kehler U, Meier U: Normal Pressure Hydrocephalus. Thieme Verlag 2014, Stuttgart New York Dehli Rio. 
10. Gliemroth J, Käsbeck E, Kehler U: Ventriculocisternostomy versus ventriculoperitoneal shunt in the treatment of hydrocephalus: $\mathrm{A}$ retrospective, long-term observational study. Clin Neurol Neurosurg 2014 122:92-6.

doi:10.1186/2045-8118-12-S1-P23

Cite this article as: Kehler: Normal pressure hydrocephalus - why

treatment is often delayed or not even initiated. Fluids and Barriers of the CNS 2015 12(Suppl 1):P23.

Submit your next manuscript to BioMed Central and take full advantage of:

- Convenient online submission

- Thorough peer review

- No space constraints or color figure charges

- Immediate publication on acceptance

- Inclusion in PubMed, CAS, Scopus and Google Scholar

- Research which is freely available for redistribution

Submit your manuscript at www.biomedcentral.com/submit 